\title{
Bicarbonate and calcium-magnesium hydrochemical indicators for the assessment of human impact on the groundwater chemistry - a case study from the Holy Cross Mts. region (Poland)
}

\author{
Jan PRA $A K^{1, *}$ \\ 1 Polish Geological Institute - National Research Institute, Holy Cross Mountains Branch in Kielce, Zgoda 21, 25-953 \\ Kielce, Poland
}

Pra ak J. (2013) Bicarbonate and calcium-magnesium hydrochemical indicators for the assessment of human impact on the groundwater chemistry - a case study from the Holy Cross Mts. region (Poland). Geological Quarterly, 57 (1): 135-140, doi: 10.7306/gq.1073

\begin{abstract}
Hydrochemical indicators are widely used for assessment of groundwater chemistry. They were established mainly for mineral waters in order to understand their origin and chemical classification. In the case of freshwater, they are used occasionally because quality classifications are based on concentrations of individual components and physical properties in relation to the permissible standards established for water intended for human consumption. Natural in temperate climate, bicarbonate-calcium and bicarbonate-calcium-magnesium waters are commonly used for drinking. In many places, ions emitted from pollution outbreaks have already caused chemical changes of water and it is often the first symptom of their contamination. The author has evaluated the scope and trends of these changes in the groundwater of the Holy Cross Mts. region in Poland using the bicarbonate and calcium-magnesium indicators.
\end{abstract}

Key words: freshwater, hydrochemical indicators, anthropogenic hazard, Holy Cross Mts.

\section{INTRODUCTION}

The aim of the study was to assess the impact of anthropogenic pollution on the chemical composition of fresh groundwater using bicarbonate and calcium-magnesium hydrochemical indicators. The effect of pollution on the groundwater chemistry is the subject of regional hydrogeological studies. For the study area in Poland (Fig. 1), the synthesis of the results of the investigations is presented in the monographic publication entitled "Regional Hydrogeology of Poland - Volume I" (Krajewski and Woźnicka, 2007; Małecka et al., 2007; Pra ak, 2007). The results of this study indicate that, in many cases, water chemistry has already been locally modified by its pollution. A significant impact of pollutants, including nitrates, on the water quality was also recorded in the springs of the Małopolska region (Chełmicki and Siwek, 2001). Anthropogenic pollution of groundwater by nitrates and chlorides takes place also in other countries of the world. Zahn and Grimm (1993) described it from Bavaria, Germany. In California (USA), nitrogen concentrations in the $\mathrm{NO}_{3}^{-}$ion in a number of research points exceeded the threshold value for drinking water $\left[10 \mathrm{~N}\left(\mathrm{NO}_{3}^{-}\right) \mathrm{mg} / \mathrm{L}\right]$, and were locally up to $50 \mathrm{mg} / \mathrm{l}$. However, an increase in the concentrations was observed there only after 1980 (Williams et al., 1998). High concentrations of nitrates are also found in the Woodbine aquifer of Texas (Hudak and Sanmanee, 2002). The

\footnotetext{
*E-mail address: jan.prazak@pgi.gov.pl
}

Received: August 22, 2012; accepted: December 20, 2012; first published online: February 15, 2013 effect of urbanization on groundwater pollution by major ions and nitrates was also found in the provinces of Tajeon and Nawmon in Korea. In Tajeon province, the maximum concentrations of ions of anthropogenic origin were as follows: $\mathrm{Na}^{+}$ $101 \mathrm{mg} / \mathrm{l}, \mathrm{K}^{+} 13.2 \mathrm{mg} / \mathrm{L}, \mathrm{Cl}^{-} 389 \mathrm{mg} / \mathrm{L}, \mathrm{SO}_{4}^{2-} \mathrm{mg} / \mathrm{L}, 102 \mathrm{mg} / \mathrm{L}$ and $\mathrm{NO}_{3}^{-167} \mathrm{mg} / \mathrm{L}$ (Chan, 2001). Hydrogeochemical processes affecting the mutual exchange of major ions are described based on the example of groundwater from Namwon province (Kangjoo et al., 2005). Processes affecting the chemical composition of groundwater have been studied, among others, also in the Thirumanimuttar Basin of India (Vasanthavigar et al., 2009) and in many other areas.

The author assessed the impact of anthropogenic pollution on the chemical composition of groundwater for the Świętokrzyskie Voivodeship in Poland on the basis of the results of regional groundwater quality monitoring. In the regional geological settings and also under climatic conditions of Poland, natural (i.e., not anthropogenically changed) fresh groundwater is mainly of bicarbonate-calcium $\left(\mathrm{HCO}_{3}-\mathrm{Ca}\right)$ and bicarbonate-calcium-magnesium $\left(\mathrm{HCO}_{3}-\mathrm{Ca}-\mathrm{Mg}\right)$ types, i.e. the content of each of the remaining major ions $\left(\mathrm{Na}^{+}, \mathrm{K}^{+}, \mathrm{SO}_{4}^{2-}, \mathrm{Cl}^{-}\right)$ and nitrates $\left(\mathrm{NO}_{3}^{-}\right)$should be greater than $20 \% \Sigma \mathrm{meq} / \mathrm{L}$ of anions or $\Sigma \mathrm{meq} / \mathrm{L}$ of cations.

\section{STUDY AREA}

The study area is approximately $12,000 \mathrm{~km}^{2}$ in size and covers the Holy Cross Mts. region and adjacent areas of the Świętokrzyskie Voivodeship. This is an upland area bounded to 


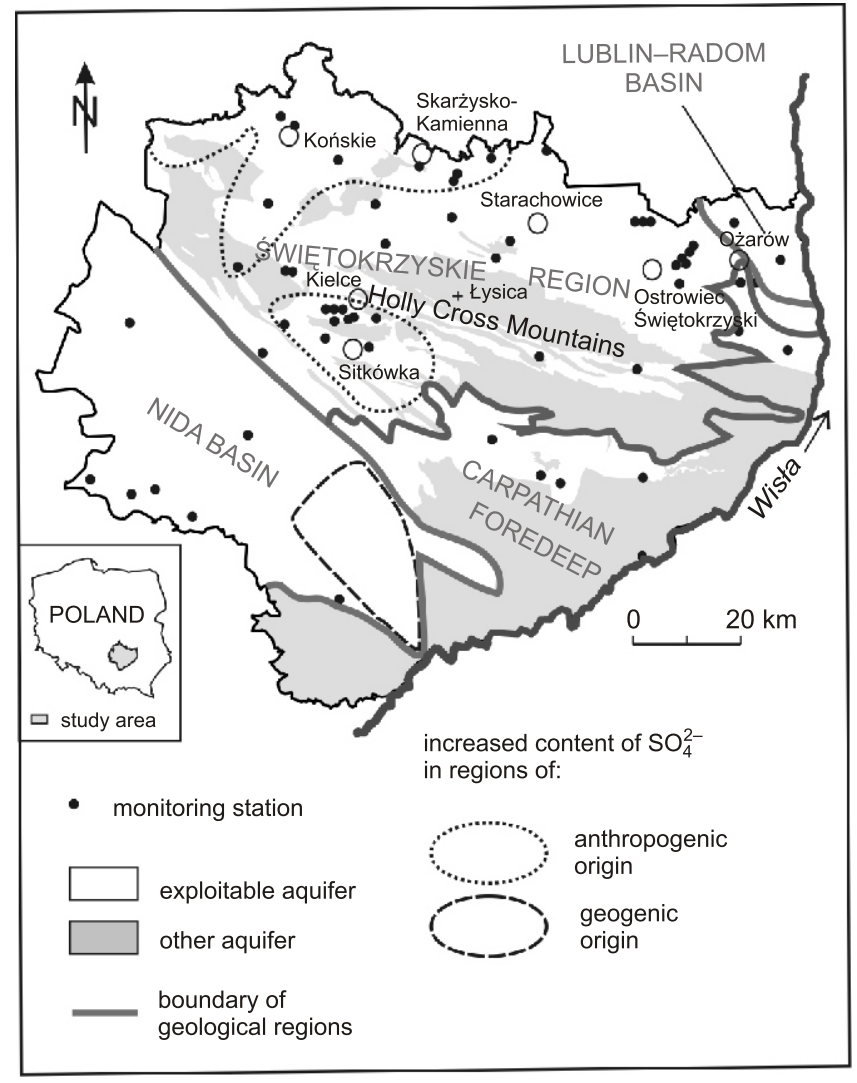

Fig. 1. Study area with location of monitoring stations shown (according to Pra ak 2002a, b)

the east and south-east by the Vistula River valley. The most elevated area is the Holy Cross Mountains, with the highest hill attaining an elevation of $611 \mathrm{~m}$ a.s.l. The geological structure of the basement includes Paleozoic and Mesozoic sedimentary rocks of Caledonian, Variscan and Alpine orogens. Younger Neogene deposits occur over a considerable area in the southeastern part of the voivodeship (Peryt and Piwocki, 2004). Quaternary deposits form a discontinuous cover, from several to about $50 \mathrm{~m}$ in thickness. Groundwater is stored in rocks of various ages and very different lithology (Krajewski and Woźnicka, 2007; Małecka et al., 2007; Pra ak, 2007). Permeable rocks that compose exploitable aquifers cover approximately $75 \%$ of the voivodeship area and they are dominated by carbonate-rich varieties. Over the remaining $25 \%$ of the area, the rocks are semipermeable and impermeable. Depths to the freshwater are about 300-400 m. Groundwater monitoring stations capture water from usable aquifers of various ages: Quaternary, Neogene, Cretaceous, Jurassic, Triassic, Permian and Devonian.

\section{ANTHROPOGENIC POLLUTION}

Undoubtedly, a small (a few percent) proportion of $\mathrm{SO}_{4}^{2-}$, $\mathrm{Cl}^{-}, \mathrm{NO}_{3}^{-}, \mathrm{Na}^{+}$and $\mathrm{K}^{+}$ions in groundwater is of geogenic origin, being its natural feature. Studies on the relationship between the natural concentrations of $\mathrm{F}^{-}, \mathrm{NO}_{3}^{-}, \mathrm{Ca}^{2+}$ and $\mathrm{Cl}^{-}$and the rock basement in Norway can be the example (Banks and Reimann, 1995). However, if the ions occur at greater concentrations and cause a decrease in the proportion of $\mathrm{HCO}_{3}^{-}$in $\Sigma$ meq/L of anions or total amount of $\mathrm{Ca}^{2+}$ and $\mathrm{Mg}^{2+}$ in $\Sigma$ meq/ $\mathrm{L}$ of cations to below $80 \%$, in areas where no ascent of mineralized water takes place, then they reflect the impact of anthropogenic pollution on groundwater.

Changes in the water chemistry at different monitoring points are caused by local pollution. The only exception is the $\mathrm{SO}_{4}^{2-}$ ion, whose increased proportion in the total water mineralization occurs mainly in the northern and central part of the study area, where its origin is probably related to the emission of sulphur compounds from steel and cement and lime plants located in the following towns: Końskie, Skar ysko-Kamienna, Ostrowiec Świętokrzyski, O arów, Kielce and Sitkówka (Fig. 1). In the southern part of the study area, in the region of occurrence of near-surface mineralized water $(<100 \mathrm{~m})$, sulphates are of geogenic origin (Pra ak, 2002b, c), but the region is excluded from the analysis that focused exclusively on anthropogenic pollution. Groundwater chemistry is also affected by low stack emission, fertilization of arable land with manure and synthetic fertilizers, use of sodium chloride for snow removal from roads, discharge of untreated wastewater into the ground, and the activity of industrial plants that use a variety of easily soluble salts, acids or bases for manufacturing processes without adequate protection against their release into the soil and water.

In recent years, particularly after 1990, more and more intensive efforts have been taken to eliminate pollution sources and to limit emissions of harmful substances into the soil and water. The effects of these actions are not instantaneous. The residence time of fresh groundwater in the rock mass is usually from several to tens of years, and sometimes even longer. Their present-day chemical composition is often affected by historical pollution impacts from currently absent pollution outbreaks. It means that even after the elimination of the pollution outbreak, we can still observe its effects.

\section{METHODS AND MATERIALS}

The assessment of the extent and nature of changes in the ionic composition of fresh groundwater has been carried out based on the results of regional monitoring of groundwater quality in the Świętokrzyskie Voivodeship during the period of 1992-2005. The study was performed at the Holy Cross Mountains Branch of the Polish Geological Institute in Kielce (Pra ak et al., 1996; Pra ak, 2002a). In 2005, the monitoring network included 104 survey points (active drilled boreholes, hydrogeological research boreholes, hand-dug boreholes and springs). Water samples for testing were collected at a frequency of once a year. Chemical analyses were performed at the Central Chemical Laboratory of the PGI in Warsaw. Bottles of water were prepared and filled with fixative at the laboratory, and water samples were delivered to the laboratory within the required time of 24-48 hours.

The results of chemical analyses of water samples taken from drilled and hydrogeological research boreholes from a depth of 30-250 and TDS below $1000 \mathrm{mg} / \mathrm{L}$, were the only ones selected to study the ionic composition of groundwater. Analyses of water samples from hand-dug boreholes extracting local near-surface groundwater (the most vulnerable to contamination) were omitted. Those results of analyses are reliable for chemical studies of water, for which the error is $\leq 5 \%$ [analytical error "Z" $=(\Sigma$ meq of anions $-\Sigma$ meq of cations $) / \Sigma$ meq (anions+cations) $\times 100 \%$ ]. As a result of the selection, only 57 out of 104 monitoring points were included for further study.

The diversity and changes in groundwater mineralization were assessed by examining the proportion of each of the major ions. Apart from $\mathrm{Ca}^{2+}, \mathrm{Mg}^{2+}, \mathrm{Na}^{+}$and $\mathrm{K}^{+}$cations and $\mathrm{HCO}_{3}^{-}$, 
$\mathrm{SO}_{4}^{2-}$ and $\mathrm{Cl}^{-}$anions, the author also included the $\mathrm{NO}_{3}^{-}$anion into the investigations. It occurs at increasingly greater concentrations in fresh groundwater. For each chemical analysis, the percentages of individual anions in the sum of anions and individual cations in the sum of cations have been calculated. In the case of cations, the total proportion of the $\mathrm{Ca}^{2+}$ and $\mathrm{Mg}^{2+}$ ions, dominant among them, have also been determined. Based on the results of the investigations, groundwater chemical types have been determined. According to the commonly used classification of Altowski-Szwiec, the chemical type of groundwater is determined by the ions that are present in the amount of at least $20 \% \pm 3 \Sigma \mathrm{meq} / \mathrm{L}$ of anions $=\Sigma \mathrm{meq} / \mathrm{L}$ of cations.

\section{HYDROCHEMICAL INDICATORS}

The impact of anthropogenic pollution on the chemical composition of groundwater is generally assessed based on the content of ions of anthropogenic origin, e.g.: $\mathrm{Cl}^{-}, \mathrm{SO}_{4}^{2-}, \mathrm{NO}_{3}^{-}$, $\mathrm{Na}^{+}$or $\mathrm{K}^{+}$, most often expressed in $\mathrm{mg} / \mathrm{L}$. In this paper, it is assessed based on the degree of reduction of the proportion of natural ions $\left(\mathrm{HCO}_{3}^{-}, \mathrm{Ca}^{2+}\right.$ and $\left.\mathrm{Mg}^{2+}\right)$ in the ionic composition of water, replaced by ions coming from pollution sources. For this purpose, it has been examined how the bicarbonate and calcium-magnesium indicators change under the influence of pollution. The bicarbonate indicator shows the percentage of the $\mathrm{HCO}_{3}^{-}$anion in total anions in meq/L, and the calcium-magnesium indicator shows the combined proportion of $\mathrm{Ca}^{2+}$ and $\mathrm{Mg}^{2+}$ ions in total cations in $\mathrm{meq} / \mathrm{L}$. These indicators are calculated for a set of chemical analyses from 57 selected survey points during the 14 years of groundwater monitoring (1992-2005). The trends in their changes have been examined.

\section{RESULTS AND DISCUSSION}

\section{GROUNDWATER HYDROCHEMISTRY}

The results of monitoring studies have shown that the contribution of the individual major ions to the total dissolve solids content varies in space and time, and the $\mathrm{SO}_{4}^{2-}, \mathrm{Cl}^{-}$and $\mathrm{NO}_{3}^{-}$ions are often at higher concentrations. In many monitoring points, the changes are very clear, but their range usually does not determine the suitability of the water for drinking purposes. Their increased proportions in the water, however, cause a reduction in the proportion of natural ions, mainly $\mathrm{HCO}_{3}^{-}$. In many cases, these changes are so significant that they lead to a change in the type of water chemistry. It was found that the participation of at least one other major ions (originating from some pollution sources) in the tested waters frequently exceeded $20 \% \pm-3 \Sigma \mathrm{meq} / \mathrm{L}$ (Table 1$)$. In addition to the above-mentioned, the following chemical types of groundwater were found:
$\mathrm{HCO}_{3}-\mathrm{SO}_{4}-\mathrm{Ca} ; \mathrm{HCO}_{3}-\mathrm{SO}_{4}-\mathrm{Ca}-\mathrm{Mg} ; \mathrm{HCO}_{3}-\mathrm{SO}_{4}-\mathrm{Cl}-\mathrm{Ca} ; \mathrm{SO}_{4}-$ $\mathrm{HCO}_{3}-\mathrm{Cl}-\mathrm{Ca}-\mathrm{Mg}$ and others. A special case is the type $\mathrm{HCO}_{3}-\mathrm{NO}_{3}-\mathrm{Ca}-\mathrm{Mg}$, in which the concentrations of nitrates are above $20 \% \Sigma \mathrm{meq} / \mathrm{L}$ of anions, indicating significant pollution of the groundwater by nitrates.

\section{TRENDS IN GROUNDWATER CHEMISTRY}

Trends in groundwater chemistry in the period of monitoring in the years 1992-2005, defined by the bicarbonate and calcium-magnesium indicators, show the following relationships:

- Bicarbonate indicator: an increasing trend at 12 survey points, a stable trend at 20 survey points, and a decreasing trend at 25 survey points. It means that the proportion of this anion constantly decreases at 25 monitoring points (44\%). It is displaced by $\mathrm{SO}_{4}^{2-}, \mathrm{Cl}^{-}$and $\mathrm{NO}_{3}^{-}$ions of anthropogenic origin. The spatial distribution in the trends of these changes in the voivodeship area shows a mosaic pattern (Fig. 2).

- Calcium-magnesium indicator: it shows an increasing trend at 8 survey points, a stable trend at 47 survey points, and a decreasing trend at 2 survey points. It means that a decreasing trend with a simultaneous increase in the proportion of $\mathrm{Na}^{+}$or $\mathrm{K}^{+}$ions emitted likely from pollution outbreaks is found only at two survey points (4\%). The spatial distribution in the trends of these changes also shows a mosaic pattern in the study area (Fig. 3).

The characteristic trends in the changes of the indicators of freshwater chemistry from the four selected monitoring points are shown in the charts presented below (Fig. 4).

The analysis of changes in water chemistry showed that the bicarbonate indicator is more responsive to the groundwater contamination than the calcium-magnesium indicator. Anions emitted from pollution sources are in fact more mobile than cations and they much more strongly affect water chemistry. Depending on the values of bicarbonate indicator, the author has identified four groundwater groups differing in the degree of the effect of anthropogenic pollution on groundwater chemistry:

A $\mathrm{HCO}_{3}^{-}>80 \%$ - groundwater of natural chemical composition,

B $\mathrm{HCO}_{3}^{-} 60-80 \%$ - groundwater of slightly changed chemical composition,

C $\mathrm{HCO}_{3}^{-} 40-60 \%$ - groundwater of moderately changed chemical composition,

D $\mathrm{HCO}_{3}^{-}<40 \%$ - groundwater of strongly changed chemical composition.

In 2005, among 57 survey points of regional monitoring in the Świętokrzyskie Voivodeship, the water had a natural chemical composition at $21(37 \%)$ survey points, it was slightly changed by anthropogenic factors at $26(46 \%)$ points, moder-

Variability ranges of the percentages of individual anions and cations in groundwater of the Swiętokrzyskie Voivodeship in the period of 1992-2005

\begin{tabular}{|c|c|c|c|c|c|c|c|c|c|}
\hline \multirow{2}{*}{ Value } & \multicolumn{4}{|c|}{$\begin{array}{c}\text { Participation in anions } \\
{[\% \text { meq/L] }}\end{array}$} & \multicolumn{5}{|c|}{$\begin{array}{c}\text { Participation in cations } \\
{[\% \text { meq/L] }}\end{array}$} \\
\hline & $\mathrm{HCO}_{3}^{-}$ & $\mathrm{SO}_{4}^{2-}$ & $\mathrm{Cl}^{-}$ & $\mathrm{NO}_{3}^{-}$ & $\mathrm{Ca}^{2+}$ & $\mathrm{Mg}^{2+}$ & $\mathrm{Na}^{+}$ & $\mathrm{K}^{+}$ & $\mathrm{Ca}^{2+}+\mathrm{Mg}^{2+}$ \\
\hline Minimum & 5 & 0.6 & 4 & 0.3 & 43 & 2 & 1 & 1 & 58 \\
\hline Maximum & 100 & 73 & 52 & 38 & 97 & 42 & 40 & 11 & 99 \\
\hline Average & 74 & 12 & 8 & 6 & 77 & 17 & 6 & 9.9 & 94 \\
\hline Median & 75 & 10 & 7 & 6 & 77 & 17 & 4 & 0.6 & 95 \\
\hline Standard deviation & 16 & 10 & 7 & 6 & 11 & 9 & 5 & 1 & 5 \\
\hline
\end{tabular}




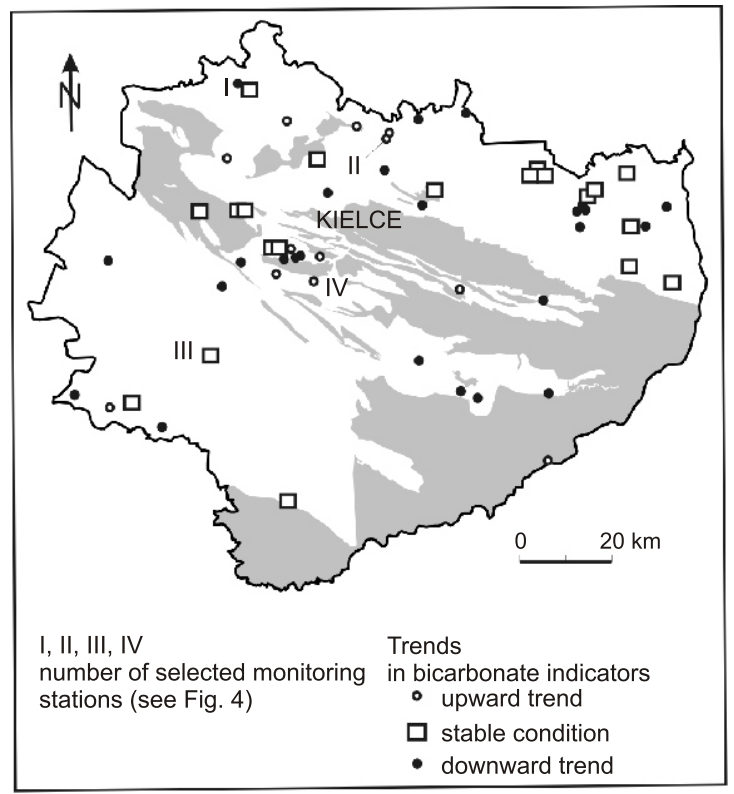

Fig. 2. Trends in bicarbonate hydrochemistry indicators of groundwater in the study area in the period of 1992-2005

Other explanationons as in Figure 1

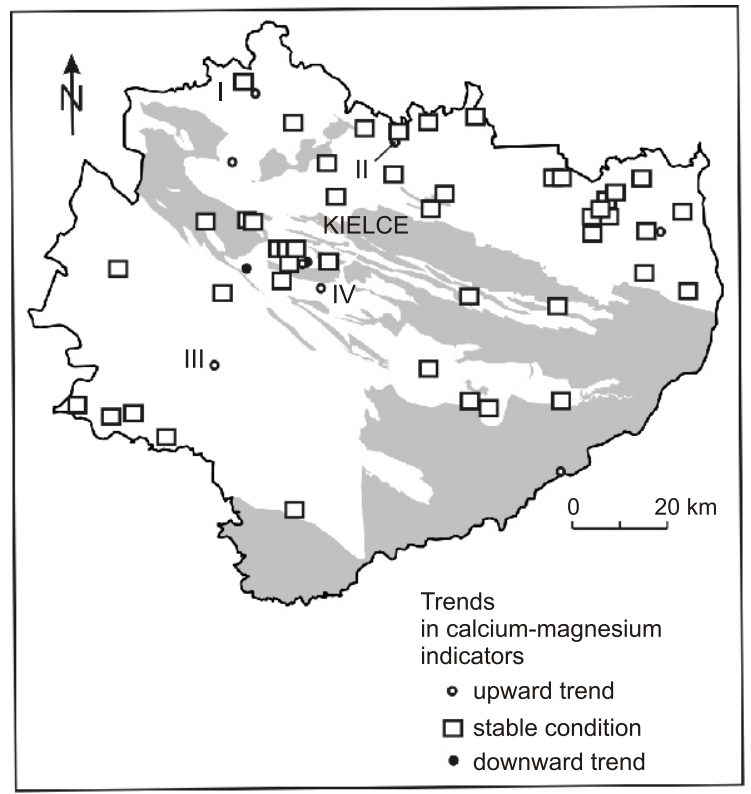

Fig. 3. Trends in calcium-magnesium hydrochemistry indicators of groundwater in the study area in the period of 1992-2005

Other explanationons as in Figures 1 and 2

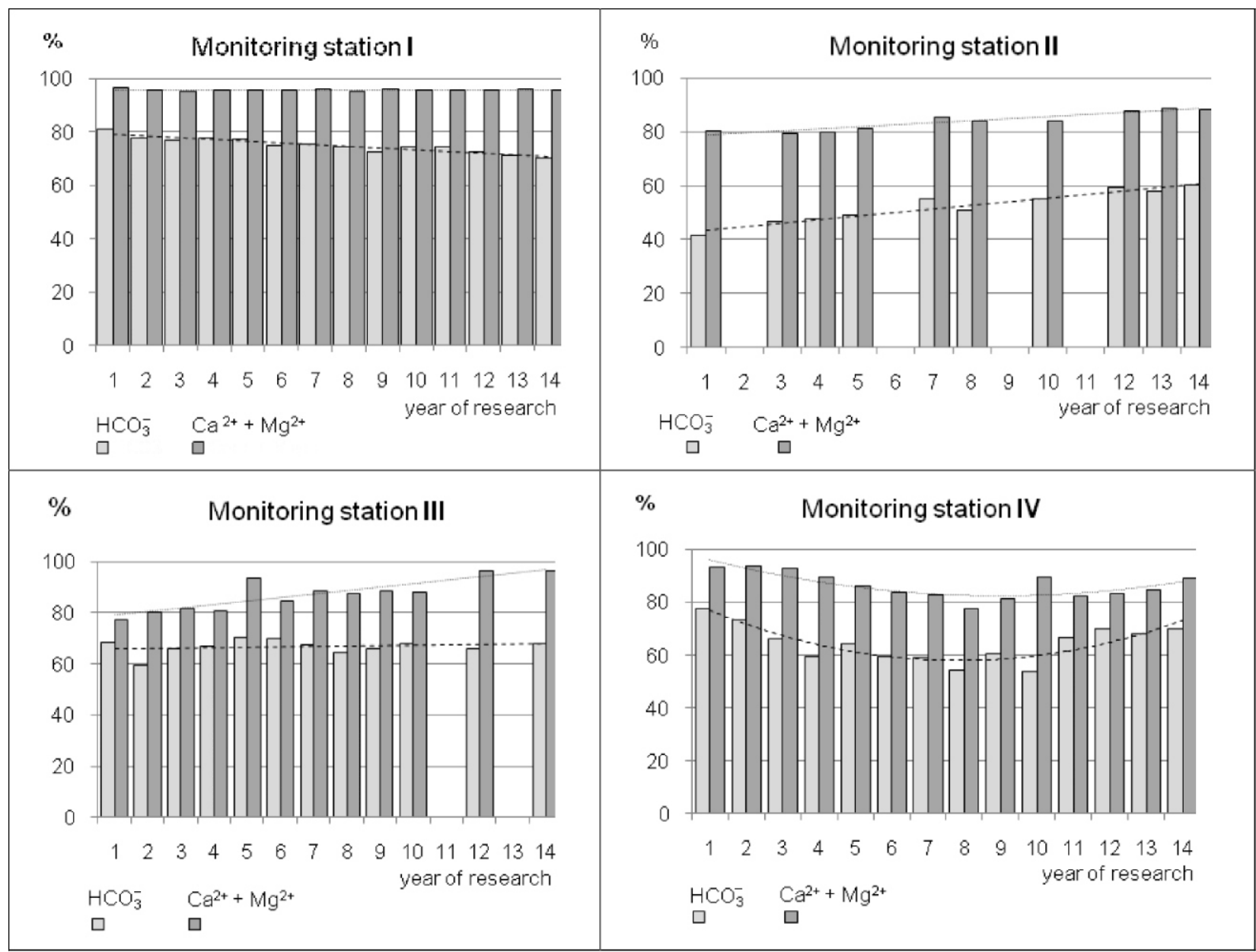

Fig. 4. Changes in the percentage of $\mathrm{HCO}_{3}^{-} \mathrm{meq} / \mathrm{L}$ in $\Sigma \mathrm{meq} / \mathrm{L}$ of anions and $\left(\mathrm{Ca}^{2+}+\mathrm{Mg}^{2+}\right) \mathrm{meq} / \mathrm{L}$ in $\Sigma \mathrm{meq} / \mathrm{L}$ of cations in groundwater at selected monitoring stations no. I-IV (for locations see Figs. 2 and 3) 
ately changed at $8(14 \%)$ points, and strongly changed at 2 (3\%) points. The distribution of the amount of these changes shows a mosaic pattern.

However, it can be seen that the largest clusters of survey points with a natural chemical composition of groundwater occur in the northeastern part of the voivodeship, and those with a changed chemical composition are observed in the northwestern, central and eastern parts (Fig. 5). Unequivocal explanation of such a distribution is difficult, especially as the trends in water chemistry evaluated using the bicarbonate indicator are different at different survey points.

When assessing the trends of the indicators we should be aware that the variation of pollution impact on the groundwater ionic composition at the monitoring point is not always a result of expansion or decline of the pollution source. The changes in

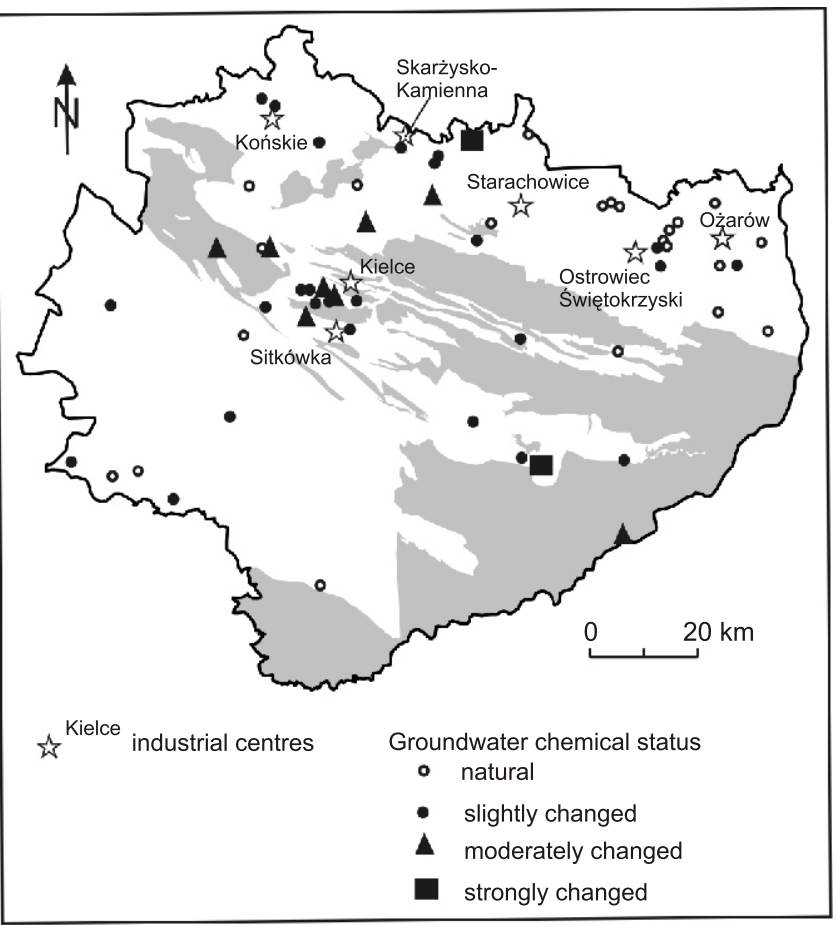

Fig. 5. Changes in the natural composition of fresh groundwater in the Świętokrzyskie Voivodeship water chemistry may arise from other causes, e.g., intense atmospheric precipitation favouring increased leaching of contamination from soil and its transfer to the aqueous solution. Pollution impact variability can also be controlled by a change in water withdrawal at the survey point, resulting in a change of its hydrodynamic position relative to the pollution outbreak.

\section{BICARBONATE INDEX}

In the light of the results, the author suggests that the commonly used groundwater quality classifications (classes I-IV), which are based mainly on the concentrations of microconstituents, be extended by indices (A, B, C, D), determined with the use of bicarbonate index. They show the degree of change in the groundwater chemistry. Here are some examples: class $I_{B}-$ the water meets quality standards for class $I$ at slightly modified chemical composition, class $I_{C}$ - the water meets quality standards for class I at moderately changed chemical composition, class $\mathrm{III}_{\mathrm{A}}$ - the water meets quality standards for class III at natural chemical composition, class III the water meets quality standards for class III at strongly changed chemical composition. In extreme cases, the water may have class $V_{A}$, and water of low mineralization $(<200 \mathrm{mg} / \mathrm{L})$ - even class $I_{D}$.

\section{SUMMARY}

In the Holy Cross Mountains, there are considerable variations in the chemistry of fresh groundwater. These are due to anthropogenic pollution of the soil-water environment mainly by sulphates, chlorides, nitrates, and subordinately by sodium and potassium. The impact of ions originating from pollution sources results in the decrease of the proportion of natural ions $\left(\mathrm{HCO}_{3}^{-}, \mathrm{Ca}^{2+}\right.$ and $\left.\mathrm{Mg}^{2+}\right)$ in the ionic composition of water. In many cases, the impact is so strong that it affects the natura chemical types of water. The amount of these changes and their trends has been assessed by the author using the bicarbonate index that is expressed by the percentage of the $\mathrm{HCO}_{3}^{-}$anion in $\Sigma \mathrm{meq} / \mathrm{L}$ of anions. Based on its value, the waters with natural, slightly changed, moderately changed and strongly changed chemical composition have been distinguished.

Acknowledgements. I thank the journal reviewers J. Chowaniec and P. Malik for their remarks and suggestions on the first version of the paper.

\section{REFERENCES}

Banks D., Reimann C. (1995) Natural concentrations of major and trace elements in some Norwegian bedrock groundwaters. Applied Geochemistry, 10: 1-16.

Chan Ho Jeong (2001) Effect of land use and urbanization on hydrochemistry and contamination of groundwater from Taejon area, Korea. Journal of Hydrology, 253: 194-210.

Chełmicki W., Siwek J. (2001) Natural and anthropogenic factors controlling spring water quality in the southern part of the Małopolska Upland (southern Poland). IAHS Publication, 269: 317-322.

Hudak P.F., Sanmanee S. (2003) Spatial patterns nitrate, sulfate, and fluoride concentration in the Woodbine aquifer of north-central Texas. Environmental Monitoring and Assessment, 82: 311-320.
Kangjoo Kim, Natrajan Rajmohan, Hyun-Jung Kim, Seok-Hwi Kim, Gab-Soo Hwang, Seong-Taek Yun, Baohua Gu, Min Joe Cho, Sang Ho Lee (2005) Evaluation of geochemical processes affecting groundwater chemistry based on mass balance approach: a case study in Namwon, Korea. Geochemical Journal, 39: 357-369.

Krajewski S., Woźnicka M. (2007) Subregion środkowej Wisły wy ynny część wschodnia. In: Hydrogeologia Polski, Tom I Wody słodkie (eds. B. Paczyński and A. Sadurski): 187-204. Państwowy Instytut Geologiczny, Warszawa.

Małecka D., Chowaniec J., Małecki J. (2007) Region górnej Wisły. In: Hydrogeologia Polski, Tom I Wody słodkie (eds. B. Paczyński and A. Sadurski): 108-158. Państwowy Instytut Geologiczny, Warszawa. 
and A. Sadurski): 108-158. Państwowy Instytut Geologiczny, Warszawa.

Peryt T.M., Piwocki M., eds. (2004) Budowa geologiczna Polski, Tom I, Stratygrafia, część 3a kenozoik, paleogen, neogen. Państwowy Instytut Geologiczny i Ministerstwo Środowiska, Warszawa.

Pra ak J. (2002a) Organizacja monitoringu jakości zwykłych wód podziemnych w sieciach krajowej i regionalnej w województwie świętokrzyskim. Regionalny Monitoring Środowiska Przyrodniczego, 3: 57-60. Kieleckie Towarzystwo Naukowe.

Pra ak J. (2002b) Chemistry and quality of groundwater in the Świętokrzyskie Province (in Polish with English summary). Biuletyn Państwowego Instytutu Geologicznego, 400: 77-90.

Pra ak J. (2002c) Anthropogenical changes in the ionic composition of fissured-karst formations of the middle and upper Devonian aquifer in the Świętokrzyskie Mountains (in Polish with English summary). Biuletyn Państwowego Instytutu Geologicznego, 404: 165-175.

Pra ak J. (2007) Subregion środkowej Wisły wy ynny część centralna. In: Hydrogeologia Polski, Tom I Wody słodkie (eds. B. Paczyński and A. Sadurski): 174-187. Państwowy Instytut Geologiczny, Warszawa.
Pra ak J., Janecka-Styrcz K., Kowalczewska G., Paciura W. (1996) Raport o jakości zwykłych wód podziemnych województwa kieleckiego na podstawie badań monitoringowych wykonanych w latach 1991-1995. Biblioteka Monitoringu Środowiska, Kielce.

Vasanthavigar M., Srinvasamoorthy K., Vijayaragavan K., Rajiv Ganthi R., Chidambaram S., Sarama V.S., Anandhan P., ManivanNan R., Vasudevan S. (2009) Hydrogeochemistry of Thirumanimuttar Basin: an indication of weathering and anthropogenic impact. International Journal of Environmental Research, 3 (4): 617-628.

Willams A.E., Lund L.J., Johnson J.A., Kabala Z.J. (1998) Natural and anthropogenic nitrate contamination of groundwater in a rural community, California. Environmental Science and Technology, 32 (1): 32-39.

Zahn M.T., Grimm W.D. (1993) Nitrate and chloride loading as anthropogenic indicators in the groundwater of an Alp foothills region in Upper Bavaria. Nitrate and chloride loadings as anthropogenic indicators. Water, Air and Soil Pollution, 68: 469-483. 